\title{
Does Integrated Reporting Enhance the Value Relevance of Organizational Capital? Evidence from the South African Context
}

\author{
Maroua Tlili \\ Manouba University, Tunisia \\ Hakim Ben Othman \\ Tunis Business School, Tunisia \\ Khaled Hussainey \\ University of Portsmouth, UK
}

\begin{abstract}
:
Despite the growing literature on Integrated Reporting adoption and the emphasis on integrated thinking capitals. In order to fill this gap, this paper investigates the value relevance of organizational capital (OC) after the mandatory adoption of integrated reporting (IR) in South Africa over the period 2006-2015. The South African context is unique since the Johannesburg Stock Exchange (JSE) is the first to mandate listed firms to adopt Integrated Reporting following King III report in March 2010. Our findings provide the first evidence, to the best of our knowledge, on the positive and significant impact of integrated reporting adoption on the value relevance of OC. We contribute to IR literature by providing new insight on the value relevance of one capital from a new perspective addressing the importance of resources as inputs to the business model highlighted by integrated thinking in the IR framework. Our findings derive various implications for the International Integrated Reporting Council, managers, decision makers, and the research community.
\end{abstract}

Keywords: Integrated Reporting, Value relevance, Organizational Capital, South Africa

\section{Introduction}

Our research is strived by the emergence of Integrated Reporting (IR hereafter) in response to the increasing demand of different stakeholders that rapidly becomes a debated reporting trend. The traditional reporting relying on financial information no longer provides enough information to different users (Lev and Zarowin, 1999; Reimsbach et al., 2017). Previous research argues that non-financial information is considerably more useful to investors (Eli and Lev, 1996). Consequently, additional information has gathered bigger attention by different stakeholders because of the increasing importance of environmental, social and governance issues (Cahan et al., 2016; Martínez-Ferrero and Frías-Aceituno, 2013; Stewart, 2015). Interlinking both financial and non-financial information in an integrated fashion leads to a better understanding, and thus improves assessment of the firm's business performance (Eccles et al., 2010).

To respond to the growing needs of different stakeholders, the International Integrated Reporting Council (IIRC hereafter) released the IR framework that emphasizes linking financial 
and non-financial information in the integrated report. The international integrated reporting framework (2013) defines IR as “concise communication about how an organization's strategy, governance, performance and prospects, in the context of its external environment, lead to the creation of value over the short, medium and long term" and proposes "to explain to providers of financial capital how an organization creates value over time" (IIRC, 2013, p. 7). Similarly, King III report in South Africa defines IR as "a holistic and integrated representation of the company's performance in terms of both its finance and sustainability" (IDSA, 2009, p. 108). As a result, a combined report became a tool to improve the quality of information communicated to capital providers (IIRC, 2013; Serafeim, 2015). In addition, it also improves the firm's ability to meet strategic goals (Churet and Eccles, 2014). Consequently, regulators and capital markets authorities start to recommend and require IR adoption.

Beyond the connectivity of information, IR focuses on resources that the organization use, defined as capitals and identified as "stocks of value that are increased, decreased or transformed through the activities and outputs of the organization" (IIRC, 2013, p. 11). The cornerstone of this emphasis is integrated thinking, considered as the process of IR (IIRC, 2013). Hence, IR differs in taking into consideration the different capitals and their ability to generate value. The framework classifies the capitals in six categories: financial, manufactured, human, natural, social and relational, and intellectual. The IR framework classifies organizational capital (OC hereafter) as a component of intellectual capital. Moreover, OC is highly based on information technology converted to knowledge through human capital. As a consequence, the importance of $\mathrm{OC}$ relies on the knowledge accumulated that has to be constantly updated to avoid organizational shock in a rapidly changing technology environment (Samaniego, 2006).

Due to the increasing importance of OC, a significant stream of literature focused on the importance of OC in improving business and financial performance. In fact, research proves that $\mathrm{OC}$ has a direct and positive impact on organizational performance and business value creation (Andreeva and Garanina, 2016; María Díez et al., 2010). Furthermore, OC enhances business performance, competitive advantage, and innovativeness ability (Lev et al., 2009; Carmona-Lavado et al., 2010; Martín-de-Castro et al., 2006; Chen et al., 2004). Lev et al. (2016) argue that despite the macro and micro levels benefits driven from OC, an important portion of the investment in OC is not tracked. More specifically, a small stream of research assessed the value relevance of OC using monetary measure. Lev et al. (2016) argue that measuring $\mathrm{OC}$ is important for managers to make strategic decisions that affect both internal and external operations. In addition, valuing OC allows investors to assess its performance in 
terms of return on investment (Lev et al., 2016). Researchers attempted to assess the value relevance of OC investment to the capital providers. The limited evidence provided in the literature provides evidence that OC is value relevant to investors (Lev et al., 2009; Eisfeldt and Papanikolaou, 2013). Hence, investigating OC within a highly developing reporting environment is as interesting as useful for both practitioners and academicians.

In reviewing IR literature, one finds a large stream of researches focusing on IR adoption, its determinants and consequences on firm valuation (García-Sánchez et al., 2013; Frías-Aceituno et al., 2013; Jensen and Berg, 2012). Although the IR framework underlines capitals as the fundamental components of integrated thinking and reporting, prior researches focused mainly on the financial and non-financial reporting. Hence, recent calls urge to investigate the advocates of IR about the six capitals (de Villiers et al., 2014; Velte and Stawinoga, 2016; Dumay et al., 2016). In particular, OC is not investigated under the IR approach in spite of the prior evidence on its impact on firm performance. In order to fill the gap, we intend to answer the following research question: Does the mandatory IR adoption enhance the value relevance of OC?

Hence, the present study contributes to the literature by providing new insight about the value relevance of one capital. Indeed, we examine the issue from a new perspective addressing the importance of resources as inputs to the business model highlighted by integrated thinking in the IR framework. We investigate whether the usefulness of OC investment is enhanced after the IR adoption. To the best of our knowledge, this is the first study that emphasizes OC by comparing the value relevance of OC before and after the mandatory IR adoption in South Africa for the period 2006-2015. The findings align with our main hypothesis,-IR adoption has a significant positive impact on the value relevance of OC. The evidence provided enhances the understanding of IR not only for the South African context but also for a broader audience. First, it contributes to IIRC's endeavors to respond to market calls for a more coherent, consistent and comparable reporting frameworks ${ }^{1}$. Second, our results are of great interest to managers and decision makers. The adoption of IR allows a better understanding of the value creation process through integrated thinking, which enhances a better decision making about resource allocation. In addition, the findings withstand the importance of $\mathrm{OC}$ as value driver,

\footnotetext{
${ }^{1}$ The IIRC launched an initiative in response to market calls aiming at communicating about the direction, content and ongoing development of reporting frameworks, standards and related requirements; identify practical ways and means by which respective frameworks, standards and related requirements can be aligned and rationalized; and share information and express a common voice on areas of mutual interest, where possible, to engage key regulators. Further information is provided in IIRC website http://integratedreporting.org/corporate-reportingdialogue/
} 
thus the necessity to invest in this resource. Third, an important implication may be drawn for the research community in regards to the focus on capitals. Future research is urged to investigate the interaction between the different capitals as inputs and outcomes in order to further comprehend the value creation process.

We organize the paper as follows. Section 2 reviews prior research. Section 3 develops the research hypotheses. In section 4, we explain the research design and section 5 discusses our findings. Section 6 concludes.

\section{Background and literature review}

To outstep the traditional corporate reporting limitations and respond to the evolving stakeholders' needs, the Global Reporting Initiative and the Prince of Wales' Accounting for Sustainability Project founded the IIRC in December 2010. The purpose was to create a globally accepted reporting framework that provides guidelines on integrating financial, social, environmental and governance information in a clear, concise and comparable format (GRI, 2012). Later, the council issued its first version of the Integrated Reporting framework in December 2013 that rapidly gained the attention of practitioners and academics. It describes IR as "a concise communication about how an organization's strategy, governance, performance and prospects, in the context of its external environment, lead to the creation of value over the short, medium and long term"(IIRC, 2013, p. 7).

The primary aim of IR is to "improve the quality of information available to providers of financial capital to enable more efficient and productive allocation of capital" (IIRC, 2013, p. 4). Furthermore, the IR framework emphasizes the short, medium and long-term consequences of an extensive set of capitals. The IIRC's particular approach relies on reporting on six capitals defined as "stocks of value that are increased, decreased or transformed through the activities and outputs of the organization" (IIRC, 2013, p. 11). The framework distinguishes six categories of capitals - financial, manufactured, intellectual, human, social and relationship, and natural - to explain how business activities consume capitals as inputs and transform them in outputs that generate outcomes expressed in terms of effects on the capitals (IIRC, 2013).

Prior to the creation of IIRC, the South African King Committee on corporate governance released the King III report, which defines IR as "a holistic and integrated representation of the company's performance in terms of both its finances and its sustainability" (IDSA, 2009, p.108). Hence, IR framework and King III emphasize both financial and non-financial information when assessing the value creation process. Yet, King III report is more stakeholderoriented and highlights sustainability and governance issues. Integrated reports should focus on 
interlinking financial to sustainability reporting to fulfill stakeholders' needs (IDSA, 2009). In fact, one of the principles dictated by the report is that "Sustainability reporting and disclosure should be integrated with the company's financial reporting" (IDSA, 2009, p.108). Within the scope of sustainability, King III report underlined the triple-context approach, as an elevator of the company's potential to value creation (IDSA, 2009).

Shortly after the release of IIRC in 2013, the Integrated Reporting Committee of South Africa recognized the IR framework in $2014^{2}$. Later, the South African King Committee on corporate governance released King IV report in 2016. The recent report highlights integrated thinking that underpins the consideration of the organization as a part of the society, the stakeholderinclusive approach, the sustainable development and the IR (IDSA, 2016). Furthermore, it introduces "the triple context" in reference to the economy, society and environment represented by a set of six capitals. In fact, King IV report adopts IIRC's definition and categorization of capitals and considers the triple context and capitals as "alternative lenses" and "pathways to integrated thinking and sustainable development" (IDSA, 2016, p. 24). In consequence, King IV report adds to its previous version the emphasis on integrated thinking and capitals similarly to IR framework.

The South African context is unique to conduct our research. Indeed, Johannesburg Stock Exchange (hereafter JSE) is the single and exclusive to mandate listed firms to adopt IR following King III report guidelines, in March 2010. Listed firms on JSE were required to issue their integrated reports for fiscal years starting from March $1^{\text {st }}$ 2011. The adoption of IR was on a "comply or explain" basis. Mandating IR by the JSE was a development of the practices already established since the 1990s. In addition to the compliance with king reports, the JSE was the first stock exchange to issue the Socially Responsible Investment (SRI) Index in 2004 including 41 out of 74 companies (JSE, 2004). The principle of the SRI index is to identify companies that integrate the Triple Bottom Line (TBL hereafter) principle into their business activities (JSE, 2004). The index is based on the three pillars of TBL: environmental sustainability, economic sustainability, and social sustainability. Furthermore, it relies on the corporate governance principles emphasized by the King II report on corporate governance. Sonnenberg and Hamann (2006, p. 319) estimated that the SRI index "has increased awareness of corporate citizenship among JSE listed companies, and its most significant effect has arguably been on those companies that otherwise would have had limited exposure to

\footnotetext{
${ }^{2}$ After the release of the IR framework in December 2013, the IR framework was endorsed by the Integrated Reporting Committee of South Africa in March 2014. The IRC is a national body that provides direction on matters relating to integrated reporting and integrated thinking in South Africa through technical information and guidance, conferences and other activities. https://integratedreportingsa.org/integrated-reporting/guidance/
} 
sustainability issues". According to multiple professional bodies, JSE is a leader in several areas. Indeed, the JSE has the largest market capitalization among the African countries with US\$ 1,033,209.0 million in 2014 (KPMG, 2014). As for the market capitalization by industry, the consumer goods industry followed by basic materials hold up to $54 \%$ of the total market capitalization. In addition, African equity markets witnessed a significant increase in the volume of Initial Public Offerings IPOs in 2017 which was mainly driven by activity in South Africa (PwC, 2018).

The emergence of IR is a result of the continuous change in the reporting environment in order to fulfill different stakeholders' needs. For that purpose, researchers use multiple theories to improve our understanding of disclosure practices such as agency, stakeholder and institutional and legitimacy theory.

According to the IR framework (2013), IR's primary purpose is to fulfill capital providers' needs congruently with agency theory which considers the firm as a nexus of contracts between stockholders (Jensen and Meckling, 1976). On the other hand, the King III report emphasizes the stakeholder-approach. Consequently, the production of integrated reports, which encompasses the information contained in traditional financial statements, is justified by the stakeholder theory. Stakeholder theory (Freeman, 1984), according to which organizations should create value for all stakeholders, takes into account the expectations of stakeholders on relevant disclosure. The theory considers the contract between the company and the society in a wider perspective than agency theory. In fact, Hill and Jones (1992, p. 131) developed a new paradigm, stakeholder-agency theory, suggesting that the firm can be seen as "a nexus of resource holders". It comprehends all the contractual relationships between different stakeholders.

Nevertheless, IR is considered as a result, not a process. In fact, the framework identifies IR as "a process founded on integrated thinking" and defines the latter as "active consideration of the relationship between different factors affecting the company's value-creation processes" (IIRC, 2013, p. 33). Indeed, IR is considered "the visible part of what is happening below the surface - namely "integrated thinking" and "integrated decision-making" (Churet and Eccles, 2014, p.8). Research debates that the adoption of IR framework fostered integrated thinking (Guthrie et al., 2017). Furthermore, integrated thinking enhances the sustainability view within the organization (Oliver et al., 2016), and takes into account the interdependencies between the range of factors and risks that affect an organizations' ability to create value over time (IIRC, 2013). It entails the management of short-term business requirements and constraints and value creation. Moreover, integrated thinking process relies on one key element, "how an 
organization uses, affects and makes trade-offs in relation to the six categories of capitals" (Feng et al., 2017, p.9). King IV report similarly focuses on integrated thinking and identifies integrated thinking as a founding stone of the report. Hence, integrated thinking should lead to integrated decision making which in return leads to the preparation of integrated reports. As a consequence, Integrated thinking is considered as the cornerstone for IR (Churet and Eccles, 2014; Feng et al., 2017). Accordingly, practitioners endeavor to enhance the understanding of integrated thinking and its important impact on implementing IR principles (PwC, 2013; SAICA, 2015). Consequently, it becomes evident that capitals represent significant elements in implementing integrated thinking and hence, integrated reporting.

Intellectual capital is one of the six capitals mentioned in IR framework. IIRC (2013, p. 12) defines intellectual capital as "Organizational, knowledge-based intangibles". Prior work argues that the large gap between the book value and the market value of a firm is due to the non-reported information on intellectual capital in financial statements (Bradley, 1997; Lev and Zarowin, 1999; Lev et al., 2009). Moreover, value creation no longer relies on tangible investments. As a matter of fact, intellectual capital became the main driver of economic value especially in knowledge-based and high-tech intensive organizations (Khalique, M., Bontis, N., Abdul, J., Bin Shaari and Abu Hassan, 2015). In addition, it is considered as a driver of the firm's innovation performance (Inkinen, 2015; Agostini and Nosella, 2017; Buenechea and Elberdin, 2017). The importance of IC is underlined by the Resource-Based Theory. Wernerfelt (1984, p. 172) identifies the resource as "anything which could be thought of as a strength or weakness of a given firm". Furthermore, the author considers that ultimately "what a firm wants is to create a situation where is own resource position directly or indirectly makes it more difficult for others to catch up" (Wernerfelt, 1984, p. 173).

In regards to the IR framework classification, IIRC (2013) identifies OC as a component of intellectual capital. However, the IR framework allows a different classification of capitals (IIRC, 2013). The IR framework defines OC as "tacit knowledge, systems, procedures and protocols" (IIRC, 2013, p. 12). In addition, WICI (2016, p. 15) describes OC as "business processes, data and systems that enable the organization to deliver products and services and create value". On the other hand, the literature proposes multiple definitions. Evenson and Westphal (1995, p. 2237) define OC as "the know how used to combine human skills and physical capital into systems for producing and delivering want-satisfying products". While Youndt et al. (2004, p. 338) identifies OC as the "institutionalized knowledge and codified experience stored in databases, routines, patents, manuals, structures, and the like". Furthermore, Martín-de-Castro et al. (2006, p. 328) reported "organizational capital as the 
combination of explicit and implicit, formal and informal knowledge which in an effective and efficient way structure and develop the organizational activity of the firm, that includes culture - implicit and informal knowledge; structure - explicit and formal knowledge; and organizational learning - implicit and explicit, formal and informal renewal knowledge processes". Additionally, researches debate that these organizational processes and management structures require "knowledge integration, as a formal process through which information and skills become an integral component of the routines that guide the firm's future actions" (Carmona-Lavado, et al., 2010, p. 683). The integration leads to a significant impact on the innovative capability and corporate value (Subramaniam and Youndt, 2005; Tseng and Goo, 2005; Wu et al., 2007; Menor et al., 2007). Therefore, OC enables tangible and intangible resources to generate outputs and it is considered as the firm's ability to deliver and sustain super-normal performance (Lev et al., 2009). The new approach broadens the definition of OC to consider it as an extension to the human capital since "it includes employees' willingness to cooperate, the knowledge storages, the work practices and routines, and other processes in the firm" (Schneider, 2018, p. 42). Furthermore, Lev et al. (2016) classify human capital, value and norms, knowledge and expertise, and business processes and practices as components of OC. Empirically, the body of literature on OC shows that systems and programs have a considerable positive impact on the firm performance while some authors argue that the impact is direct (Bontis, 1998; Chen et al., 2004; Cabrita and Bontis, 2008). Moreover, Yang and Lin (2009) provide evidence that $\mathrm{OC}$ predicts firm performance. Accordingly, OC contributes significantly to business performance and improves the competitive advantage of the firm (Martín-de-Castro, G., Navas-López, J. E., López-Sáez and Alama-Salazar, 2006). With respect to the relationship between $\mathrm{OC}$ and financial performance, the existing researches on this relationship conclude that the OC has an impact on financial performance since it enhances both the knowledge management and innovativeness, features that represent a strong competitive advantage in the business environment (Kamukama et al., 2011). Consistently with resource-based-view that considers a firm as a set of resources leading to sustainable advantage (Wernerfelt, 1984; Miles and Van Clieaf, 2017).

In sum, OC becomes one of the most investigated intangible assets in recent researches. It is due to the complex nature that makes it difficult to build and imitate. Besides, in a business world where physical assets are declining in terms of value creation and value relevance, the intangible assets are becoming more sophisticated and challenging to identify and measure. 


\section{Hypothesis development}

The aim of this paper is to investigate the impact of IR adoption on the value relevance of OC. The existing body of literature demonstrates the relevance of OC investment to capital providers. Indeed, Lev et al. (2009) examined the value relevance of OC using a firm-specific monetary OC measure based on selling, general and administrative expenses (SG\&A). The findings sustain the hypothesis, a positive and strong association exists between the measure and future operating performance. As for financial performance, $\mathrm{OC}$ is also positively related to stock performance. Furthermore, Eisfeldt and Papanikolaou (2013) explored the relationship between OC and expected returns. For this purpose, they developed a measure for OC based, also, on selling, general and administrative expenses. Results show that higher OC contributes to higher expected returns. Consequently, $\mathrm{OC}$ is a forward-looking asset and important in upgrading the business performance and thus the continuity of the firm.

The potential impact of IR adoption on the relevance of capitals is under-investigated in the literature. However, there is a stream of literature examining the impact of IR adoption on financial and non-financial information. In fact, Mervelskemper and Streit (2017) found, in an international context, that IR disclosures on ESG performance have a higher impact on capital market investors' perceptions than other reports, with no additional costs. This finding highlights that IR surpasses stand-alone ESG reporting, which concords with IIRC guiding principles on information connectivity. Moreover, Setia et al. (2015) provided evidence that the introduction of IR in South Africa has enhanced the disclosures on all the capitals with a higher impact on social and relational capital, consistently with the requirements of IIRC and King III report.

In addition, Baboukardos and Rimmel (2016) reported that accounting numbers, specifically Earnings, gain a higher value relevance after the mandatory adoption of IR in South Africa. They argue that such an increase in value relevance is due to the reliability of the information provided in integrated reports. On the other hand, the findings uncover the decline of value relevance of net assets which authors qualify as a "further argument in favor of the IIRC stance to assign equal importance to a wide range of "capitals" such as human, social and natural capital" (Baboukardos and Rimmel, 2016, p. 12).

Nonetheless, De Villiers and Sharma (2017) examine the IC reporting under GRI, financial and IR and conclude that IR does not provide additional information on IC. Authors explain this limitation by the nonexistence of a body supporting IC despite its important contribution to value creation (DeVilliers and Sharma, 2017). Hence, based on prior literature, we hypothesize that: 


\section{H: IR adoption enhances the value relevance of OC in South Africa.}

Research design

\section{Sample and data sources}

In order to examine the impact of mandatory IR adoption on the value relevance of OC, we compare the value relevance of firms' OC over a five-year period before the mandatory implementation of King III Report with the following five-year period, for listed companies on JSE. JSE mandated the publication of integrated reports for listed firms starting from March $1^{\text {st }}$ 2010 following the King III report recommendations. Contrarily to firms listed in JSE, firms that voluntarily adopt IR declare themselves as adopters to Global Reporting Initiative. However, the declaration is over a discontinuous time of period. Therefore, the characteristics of the South African context allow examining the largest sample of firms publishing an integrated report over six years continuously. Another feature of the South African context is that JSE requires also preparing financial statements under International Financial Reporting Standards. Accordingly, our results are not affected by any changes in the adoption of the accounting standards implemented. Consequently, we consider 2006-2010 as the pre-adoption period and 2011-2015 as the post-adoption period since the first integrated reports have been published during the fiscal year ending on February $28^{\text {th }} 2011$ onwards. Furthermore, the choice of a five-year period relies on the nature of OC.

Thomson Reuters Datastream is the source of accounting and market data used to measure all of our variables. We built a balanced sample that consists of 99 firms listed on the JSE, active during the full period (2006-2015) and has available data over 10 years. Table 1 demonstrates the sample selection criteria. Initially, we considered the entire active population of 471 companies listed in JSE. We subtracted 238 companies of the financial industry due to their specificities of OC. Then we reduced the sample by 128 active companies that are not listed in the JSE over all the period 2006-2015. Finally, we subtracted 6 companies that do not have available data on SG\&A expenses.

Table 1 - Sample selection -

Table 2 provides information about the final sample. It consists of 99 firms that belong to seven industries according to the Industry Classification Benchmark.

Table 2 - Sample classification by Industry-

The period of the study ends in the fiscal year 2015 in order to avoid any potential impact of the release of King IV report in 2016 on the market value. Panel data result in 885 observations (firm-year observations). In addition, we include industry as dummy variable Indit to control for 
industry effects within the sample. Table 3 exhibits the final number of firm-year observations. We start with 1090 observations. We drop 10 observations with missing values and 6 observations with negative book value. In addition, in order to eliminate the potential effect of outliers on the results' robustness, we trimmed all the variables at 5\%. Dropping outliers resulted in reducing the number of observations to 885 .

Table 3 - Number of observations specification -

\subsection{Model and variables definitions}

Investors' prior predictions of a firm's future performance are based on all previous available information (Scott, 2015). According to the association study introduced by Ball and Brown (1968), the share returns respond to the accounting information over a wide window of securities market reaction to accounting numbers. In order to examine the association between the market reaction accounting information, a large stream of value relevance literature use Ohlson model (1995), an accounting-based performance measure (Baboukardos and Rimmel, 2016; Hassel et al., 2005; Hirschey et al., 2001). The basic model associates the market value of the company with its Earnings and Book Value. We extended the conventional valuation by examining the association between market value and OC in a first step. Hence, we add OC to the model in order to test for our main hypothesis.

$$
M V S_{i t}=\alpha_{0}+\alpha_{1} O C_{i t}+\alpha_{2} B V S_{i t}+\alpha_{3} E P S_{i t}+\varepsilon_{i t}
$$

The dependent variable $M V S_{i t}$ is the market value of the firm, 4 months after the fiscal year end. JSE requires publishing annual reports 3 months after the fiscal year-end (JSE, 2016). In consequence, we choose 4 month-period to make sure that investors assessed the information published. As for the independent variable of interest, we measure OC following (Eisfeldt and Papanikolaou, 2013). The measure is based on Selling, general and administrative expense, reported in the income statement, which-and includes resources influencing OC (Lev et al., 2009). Besides, it was demonstrated that it contributes to long term value creation (Banker et $a l ., 2011)$. Furthermore, this type of expenditures is positively associated with OC (Venieris et al., 2015). We measure $O C_{i t}$ as follows using the law of motion (Gourio and Rudanko, 2014):

$$
O C_{i t}=\left(1-\delta_{O}\right) O C_{i, t-1}+\frac{S G A_{i t}}{c p i_{t}}
$$


Where $c p i_{i t}$ stands for consumer price index, $\delta_{O}$ as the depreciation rate of $15 \%{ }^{3}$ based on the rate used in R\&D estimation by the Bureau of Economic Analysis, and $S G A_{i t}$ as the selling general and administrative expenses for the year $t$.

As follows, an initial stock was constructed using the perpetual inventory method ${ }^{4}$ (Griliches, 1980) which relies on the steady state approach of growth rate $g$ where:

$$
\begin{gathered}
g=\frac{S G A_{t}}{O C_{t-1}}-\delta \\
g+\delta=\frac{S G A_{t}}{O C_{t-1}} \\
O C_{0}=\frac{S G A_{1}}{g+\delta}
\end{gathered}
$$

Where $g$ represents the average annual SG\&A growth rate found to be $7 \%$ in our sample.

In a second step, to capture the impact of the IR adoption on the value relevance of OC, we multiply $O C_{i t}$ by the period binary variable $D_{i t}$ that refers to the post-adoption period (2011$2015)$ if $D_{i t}$ equals to one and zero for the pre-adoption period (2006-2010). As a result, if the coefficient $\alpha_{5}$ is found to be positive and significantly different than 0 , we posit that IR enhances the value relevance of OC. If the coefficient $\alpha_{5}$ is found to be positive but not statistically different than 0 , then IR does not impact the value relevance of OC. However, if $\alpha_{5}$ is found to be negative and significantly different than 0 , it means that the new corporate trend does not improve the value relevance of OC.

Furthermore, we include three control variables, Return on equity $R O E_{i t}$, Size of the firm Size $i t$ and leverage $L E V_{i t}$ to control for the differences in the value relevance of the profitability, the size and the leverage of the firm. It is documented that the value relevance of intangibles is significant for companies with higher ROE (Aboody and Lev, 1998). Similarly, the company's size and leverage are proven to have a significant impact on the value relevance of R\&D (Lev and Sougiannis, 1996). In addition, we control for $I n d_{i t}$, the industry-specific effects. The model is presented as follows:

\footnotetext{
${ }^{3}$ The depreciation rate $15 \%$ is determined following Sliker (2007) the Bureau of Economic Analysis ${ }^{4}$ Perpetual inventory method also applied by Griliches (1980) relies on the geometric perpetual-inventory equation
} 


$$
\begin{aligned}
& M V S_{i t}=a_{0}+a_{1} O C_{i t}+a_{2} B V S_{i t}+a_{3} E P S_{i t}+a_{4} D_{i t}+a_{5}\left(O C_{i t} \times D_{i t}\right)+a_{6}\left(B V S_{i t} \times D_{i t}\right)+a_{7}\left(E P S_{i t} \times D_{i t}\right)+ \\
& +a_{8} S_{i z e_{i t}}+a_{9} R O E_{i t}+a_{10} L E V_{i t}+\sum_{j=1}^{j=7} a_{11} \operatorname{Ind} d_{i t}+e_{i t}
\end{aligned}
$$

Where,

$M V S_{i t}$ : Market value of equity of firm $i$ at time $t, 4$ months after fiscal year end

$O C_{i t}$ : OC of equity of firm $i$ at time $t$ deflated by number of shares

$B V S_{i t}$ : Book value of equity scaled by the total number of common shares of firm $i$ at time $t$

$E P S_{i t}$ : Earnings before interest and taxation of the equity of firm $i$ at time $t$ scaled by total numbers of common shares

$D_{i t}$ : Binary variable, it takes 0 for the period before King III report adoption and 1 for the postadoption period

Size $_{i t}$ : Natural logarithm of total assets of firm $i$ at time $t$

$R O E_{i t}$ : Return on equity of equity of firm $i$ at time $t$ computed by ratio Earnings before interest and taxation over Book value

$L E V_{i t}$ : Leverage of firm $i$ at time $t$ measured by total liabilities scaled by total shares outstanding $I n d_{i t}$ : Multiple dummy variable based on 7 out of 10 industries of the industry classification benchmark.

Findings

\subsection{Descriptive statistics}

Table 4 provides summary statistics of variables for the full sample, pre-adoption period of King III report and post-adoption period. $M V S_{i t}$ is on average ZAR 0.043 during the full period, 0.037 ZAR before the adoption against 0.048 ZAR after the adoption. The non-parametric Wilcoxon test shows a significant difference in $M V S_{i t}$ before and after IR adoption, which implies that the average market value per share has increased after IR adoption. Our variable of interest, $O C_{i t}$, over the full period, has a mean of 6.129 ZAR per share. The non-parametric Wilcoxon test shows that there is no significant difference in the main independent variable $O C_{i t}$ between the periods. While the means of $B V S_{i t}$ and $E P S_{i t}$ are 18.66 ZAR and 4.44 ZAR respectively. 
Regarding the control variables, the average size of our sample companies is 15.031, Leverage has a mean of 0.481 ZAR and ROE of 0.271 .

-Table 4 Descriptive statistics -

\subsection{Correlation analysis}

In our multivariate analysis, we use three independent variables and three control variables. In order to avoid predictors' high standard errors which produce incorrect estimations (Glauber, 1967), we need to inspect the potential existence of collinearity between the variables.

Table 5 provides Pearson and Spearman correlation coefficients for all variables used in our panel linear regression. We find a high correlation between $B V S_{i t}$ and $E P S_{i t}$ that indicates a potential multicollinearity problem.

-Table 5 Pearson/Spearman correlation analysis -

Nevertheless, in order to verify the existence of collinearity between the two variables, we run the Variation Inflation Factor test among independent variables. The test validates the collinearity if the VIF value is higher than 5 (Glauber, 1967). Our test shows that the highest VIF value shows 4.26 which indicates an iVIF of 0.23 higher than 0.20 as shown in Table 6 . This suggests that the level of multicollinearity between the independent variables of the model is not problematic. Furthermore, there is no evidenced correlation between BVS and EPS in the accounting literature (Ohlson, 1995). In consequence, we suggest that the correlation between $B V S_{i t}$ and $E P S_{i t}$ is not influential on the significance of the coefficients. Hence, we kept all the variables in our regression

\section{-Table 6 Variation Factor Analysis-}

To specify the model, we used Feasible Generalized Least Squares to correct for autocorrelation and heteroscedasticity (Hansen, 2007; Baltagi and Wu, 1999). We identify the autocorrelation of the first order using Wooldridge test. We detect heteroscedasticity by running Breush-Pagan test and Hausmann test that fail to reject the null hypothesis of uncorrelated individual effects. Thus, a random-effect model is more suitable for this regression.

\subsection{Results}

Our study aims at examining whether the value relevance of OC increases after the mandatory adoption of Integrated Reporting. We run a multivariate linear regression based on Ohlson Model (Ohlson, 1995).

-Table 7 Market Value Model results- 
Table 7 shows the results issued from the Feasible Generalized Least Squares (FGLS) regression.

As predicted, we find the coefficient $\alpha_{5}$ of the interaction $O C_{i t} \times D_{i t}$, that represents the OC after IR adoption, to be positive and significant $(0.000984)$ at $1 \%$ level ( $\mathrm{p}$-value $=0.000$ ). This outcome sustains our hypothesis; the mandatory IR adoption has a strong impact on the value relevance of OC. Further, the coefficient of the adoption period $D_{i t}$ is also positive $(0.00674)$ and significant at $5 \%$ level $(\mathrm{p}$-value $=0.016)$ which denotes the significance of IR adoption. In addition, the coefficient $\alpha_{7}$ of interaction $E P S_{i t} \times D_{i t}$ is positive $(0.00187)$ and significant at $1 \%$ level (p-value=0.004), contrarily to the coefficient $\alpha_{6}$ of interaction $B V S_{i t} \times D_{i t}$ which we find negative $(-0.000710)$ and significant at $1 \%$ (p-value $=0.000)$, consistently with those reported by Baboukardos and Rimmel (2016).

As regards to control variables, the coefficients $\alpha_{8}$ and $\alpha_{9}$ of $S i z e_{i t}$ and $R O E_{i t}$ respectively, are positive (0.000765) and (0.0262), and significant at $1 \%$ level, whereas the coefficient $\alpha_{10}$ of $L E V_{i t}$ is negative (-0.0199) and significant at $1 \%$ level. This entails that the impact of IR adoption on OC is more important for larger firms, with a higher return on equity and lower leverage.

\subsection{Robustness check}

To test the robustness of the main result, we adopt the recommendation of Kothari and Zimmerman (1995, p. 184) stating that the "use of both return and price models has the potential to yield more convincing evidence". In fact, several value relevance studies employ both models (Lev and Sougiannis, 1996; Aboody and Lev, 1998). Hereafter, to test the robustness of our results, we investigate the impact of IR adoption on the relationship between OC and stock returns. Therefore, we define the following model:

$$
\begin{aligned}
\mathrm{R}_{i t} & =\beta_{0}+\beta_{1} O C_{i t}+\beta_{2} B V S_{i t}+\beta_{3} E P S_{i t}+\beta_{4} D_{i t}+\beta_{5}\left(O C_{i t} \times D_{i t}\right)+\beta_{6}\left(B V S_{i t} \times D_{i t}\right) \\
& +\beta_{7}\left(E P S_{i t} \times D_{i t}\right)+\beta_{8} S_{i z e_{i t}}+\beta_{9} R O E_{i t}+\beta_{10} L E V_{i t}+\sum_{j=1}^{j=7} \beta_{11} I_{i t}+e_{i t}
\end{aligned}
$$

Where $R_{i t}$ is the annual share return of firm $i$ in the period $t$, computed following (Chalmers $e t$ al., 2011) 


$$
R_{i t}=\frac{P_{i t}-P_{i t-1}}{P_{i t-1}}
$$

Where $P_{i t}$ is the share price of firm $i 4$ months after annual reports' publication and $P_{i t-1}$ the share price of firm $i 8$ months before. As for the sample, we keep the same sample, 885 observations over the same period (2006-2015).

\section{Table 8 - Return Model results-}

Table 8 shows the results obtained from Feasible Generalized least squares regression. Congruently with Market Value model, the multivariate regression results corroborate rove our prior findings in terms of sign and significance of the coefficient $\beta_{5}$ of $\left(O C_{i t} \times D_{i t}\right)$. In fact, $\beta_{5}$ is positive (0.3862) and significant at 5\% level ( $\mathrm{p}$-value $=0.018)$.

\section{Discussion of the results}

The findings evidenced by the market and return models match with IIRC claims on the importance of capitals and their ability to create value on the short, medium and long-term (IIRC, 2013). Moreover-In fact, IR has a primary purpose to improve the information quality provided to capital providers and enables investors to access to different capitals through an integrated and long-term perspective (IIRC, 2015). Furthermore, the evidence supports the endeavors of the King Committee to achieve the integrated sustainability reporting capable of fulfilling different stakeholders' needs (IDSA, 2002; IDSA, 2009; IDSA 2016). Recent studies also prove these assertions; Lee and Yeo (2016, p. 1221) demonstrate that "Integrated reporting improves the information environment in complex firms such as firms with high intangible assets", which underlines the importance of intellectual capital information to investors provided by IR. Besides, Serafeim (2015) argues that firms adopting IR attract long-term investors. Another feature explanation of IR is that it is the ability of IR to satisfy investors' needs through more enhanced information, which overcomes existent reporting mechanisms' shortcomings (Zhou et al., 2017). A finding that contradicts de Villiers and Sharma (2017) who discuss that information provided by IR is not superior to those provided by sustainability and corporate social reporting.

Our findings can also be explained through SR lenses. Indeed, sustainability reporting literature provides strong evidence on the impact of sustainability and corporate social responsibility reporting on firm value. Indeed, investors award firms practice corporate social responsibility and disclose information on ESG performance in CSR reports (Cahan et al., 2016; MartínezFerrero and Frías-Aceituno, 2013; de Klerk and de Villiers, 2012; Schadewitz and Niskala, 
2010). Besides, a large stream of literature demonstrates the existence of a strong link between sustainability reporting and financial performance even though sustainability reporting is criticized to be disconnected from financial information (de Villiers et al., 2017). Indeed, firms that engage in sustainable activities, publish sustainability reports or disclose sustainability information in annual reports display high abnormal returns and show high financial performance indicators (Jones et al., 2007; Berthelot et al., 2012; Martínez-Ferrero and FríasAceituno, 2013).

Furthermore, IR also improves the perception of investors on capitals, another proof that confirms IR claims on the importance of capitals in the value creation process (IIRC, 2013; IDSA, 2016). In fact, the voluntary adoption of IR enhances the value relevance of ESG information better than stand-alone CSR reports (Mervelskemper and Streit, 2017). Our findings are also in line with Baboukardos and Rimmel (2016) where the results yield a strong increase in earnings value relevance after mandatory adoption in South Africa. Barth et al. (2017) also support IR claims, they conclude that IR improves external information through increasing investment efficiency and yields to higher future cash flows.

\section{Conclusion}

Our research is driven by the release of the IR framework by IIRC in 2013 and the mandatory adoption of IR in South Africa in 2010. Further, our motivation arises from the topical calls to investigate the impact of IR adoption on the firm's valuation by different stakeholders (Cheng et al., 2014; Lee and Yeo, 2016; Hsiao and Kelly, 2017; Stark and Tsalavoutas, 2018). IIRC highlights in the IR framework the importance of the manufactured, financial, natural, social, human and intellectual capitals. Furthermore, King IV report emphasizes the six capitals within "the triple context" and considers them as "pathways to integrated thinking and sustainable development" (IDSA, 2016, p. 24). This study is also derived from the scarcity of studies on the value relevance of OC and on the impact of IR adoption on the value relevance of capitals. Therefore, this study aims at contributing to the literature by examining the value relevance of OC under IR approach. Specifically, we examine the effect of the new corporate reporting on the usefulness of OC to the capital market. For that, we adopt the Ohlson (1995) model to associate the market value to OC using Eisfeldt and Papanikolaou (2013)'s measure as a proxy. Our study yields the first evidence, to the best of our knowledge, on the substantial impact of mandatory IR adoption in South Africa on the usefulness of OC to the capital providers. The evidence we provide corroborates the IIRC's and King IV report's claims on the importance of capitals. The results of this study derive various implications for regulators and practitioners. 
First, it supports the IIRC's aim to respond to market calls for an enhanced reporting framework. Furthermore, it sustains the efforts of the King Committee to a better understanding of IR in South Africa. Second, it inspires managers and decision makers to adopt IR in order to understand further the value creation process. Moreover, the evidence validates the importance of OC both in terms of business and financial performance (Lev et al., 2009; Miles and Van Clieaf, 2017). Besides, the IIRC framework puts emphasis on capitals due to their substantial impact on value creation (IIRC, 2013). In consequence, the evidence underlines the necessity to invest in $\mathrm{OC}$ as an important and valuable resource both to the organization and capital providers.

In summary, the present study adds to the ongoing debate on IR by demonstrating that the mandatory adoption of IR in South Africa creates a significant change in the OC's value relevance to the capital market. We believe that this first evidence can be of particular interest to managers to emphasize OC investment, to JSE and other capital markets, IIRC and standard setters. However, our research has certain limitations that need to be acknowledged. First, although the consultation draft of the IR framework has been available since September 2011, the definitions of capitals and integrated thinking were detailed in IR framework in 2013 followed by King IV report, released in 2016. A replicate of this study after 2016 would be interesting where investors are more informed on the importance of capitals and integrated thinking process. Second, our research focused on OC as input to the business model. Further research could explore the impact of the business activities on the capitals, the outcomes.

\section{References:}

Aboody, D. and Lev, B. (1998a) 'The value relevance of intangibles: The case of software capitalization', Journal of Accounting Research, 36(3), pp. 161-191. doi: 10.2307/2491312. Aboody, D. and Lev, B. (1998b) 'The Value Relevance of Intangibles: The Case of Software

Capitalization', Journal of Accounting Research, 36, p. 161. doi: 10.2307/2491312.

Agostini, L. and Nosella, A. (2017) 'Enhancing radical innovation performance through intellectual capital components', Journal of Intellectual Capital, 18(4), pp. 789-806. doi: http://dx.doi.org/10.1108/MRR-09-2015-0216.

Andreeva, T. and Garanina, T. (2016) 'Do all elements of intellectual capital matter for organizational performance? Evidence from Russian context', Journal of Intellectual Capital, 17(2), pp. 1-15. doi: 10.1108/14691930210412827.

Baboukardos, D. and Rimmel, G. (2016) 'Value relevance of accounting information under an integrated reporting approach: A research note', Journal of Accounting and Public Policy, 35(4), pp. 437-452. doi: 10.1016/j.jaccpubpol.2016.04.004. 
Ball, R. and Brown, P. (1968) ‘An Empirical Evaluation of Accounting Income Numbers', Journal of Accounting Research, 6(2), p. 159. doi: 10.2307/2490232.

Baltagi, B. H. and Wu, P. X. (1999) 'Unequally spaced panel data regressions with AR(1) disturbances', Econometric Theory, 15, pp. 814-823.

Banker, R. D., Huang, R. and Natarajan, R. (2011) 'Equity Incentives and Long-Term Value Created by SG\&A Expenditure', Contemporary Accounting Research, 28(3), pp. 794-830. doi: 10.1111/j.1911-3846.2011.01066.x.

Barth, M. E., Cahan, S. F., Chen, L. and Venter, E. R. (2017) 'The economic consequences associated with integrated report quality: Capital market and real effects', Accounting, Organizations and Society. Elsevier Ltd, 62(2017), pp. 43-64. doi: 10.1016/j.aos.2017.08.005.

Berthelot, S., Coulmont, M. and Serret, V. (2012) 'Do Investors Value Sustainability Reports? A Canadian Study', Corporate Social Responsibility and Environmental Management, 19(6), pp. 355-363. doi: 10.1002/csr.285.

Bontis, N. (1998) 'Intellectual capital: an exploratory study that develops measures and models', Management Decision. MCB UP Ltd, 36(2), pp. 63-76. doi:

\section{$10.1108 / 00251749810204142$}

Bradley, K. (1997) 'Intellectual capital and the new wealth of nations', Business Strategy Review, 8(1), pp. 53-62. doi: 10.1111/1467-8616.00046.

Buenechea, M. and Elberdin (2017) 'Structured literature review about Intellectual Capital and Innovation', Journal of Intellectual capital, 18(2), pp. 2-32. doi: 10.1108/IJBM-07-20130069.

Cabrita, M. D. R. and Bontis, N. (2008) 'Intellectual capital and business performance in the Portuguese banking industry', International Journal of Technology Management, 43(1/2/3), p. 212. doi: 10.1504/IJTM.2008.019416.

Cahan, S. F., De Villiers, C., Jeter, D. C., Naiker, V. and Van Staden, C. J. (2016) 'Are CSR Disclosures Value Relevant? Cross-Country Evidence', European Accounting Review, 25(3), pp. 579-611. doi: 10.1080/09638180.2015.1064009.

Carmona-Lavado, A., Cuevas-Rodríguez, G. and Cabello-Medina, C. (2010) 'Social and organizational capital: Building the context for innovation', Industrial Marketing Management. Elsevier Inc., 39(4), pp. 681-690. doi: 10.1016/j.indmarman.2009.09.003.

Chalmers, K., Clinch, G. and Godfrey, J. M. (2011) 'Changes in value relevance of accounting information upon ifrs adoption: Evidence from australia', Australian Journal of Management, 36(2), pp. 151-173. doi: 10.1177/0312896211404571. 
Chen, J., Zhu, Z. and Yuan Xie, H. (2004) 'Measuring intellectual capital: a new model and empirical study', Journal of Intellectual Capital, 5(1), pp. 195-212. doi:

10.1108/14691930410513003.

Cheng, M., Green, W., Conradie, P., Konishi, N. and Romi, A. (2014) 'The International Integrated Reporting Framework: Key Issues and Future Research Opportunities', Journal of International Financial Management and Accounting, 25(1), pp. 90-119. doi:

10.1111/jifm.12015.

Churet, C. and Eccles, R. (2014) 'Integrated reporting, quality of management, and financial performance', Journal of Applied Corporate Finance, 26(1), pp. 8-16. doi: 10.1007/978-14614-9173-6.

De Klerk, M. and De Villiers, C. (2012) 'The value relevance of corporate responsibility reporting: South African evidence', Meditari Accountancy Research, 20(1), pp. 21-38. doi: $10.1108 / 09574090910954864$.

De Villiers, C., Hsiao, P.-C. K. and Maroun, W. (2017) 'Developing a conceptual model of influences around integrated reporting, new insights and directions for future research', Meditari Accountancy Research, 25(4), pp. 450-460. doi: 10.1108/MEDAR-07-2017-0183. De Villiers, C., Rinaldi, L. and Unerman, J. (2014) 'Integrated Reporting: Insights, gaps and an agenda for future research', Accounting, Auditing \& Accountability Journal, 27(7), pp. 1042-1067. doi: 10.1108/AAAJ-06-2014-1736.

De Villiers, C. and Sharma, U. (2017) 'A critical reflection on the future of financial, intellectual capital, sustainability and integrated reporting', Critical Perspectives on Accounting. doi: 10.1016/j.cpa.2017.05.003.

Díez, J. M., Ochoa, M. L., Prieto, M. B. and Santidrián, A. (2010) 'Intellectual capital and value creation in Spanish firms', Journal of Intellectual Capital, 11(3), pp. 348-367. doi: 10.1108/14691931011064581.

Dumay, J. et al. (2016) 'Integrated reporting: A structured literature review', Accounting Forum, 40(3), pp. 166-185. doi: 10.1016/j.accfor.2016.06.001.

Eccles, R. G., Cheng, B. and Saltzman, D. (2010) The landscape of integrated reporting reflections and next steps, Harvard Business Review.

Eisfeldt, A. L. and Papanikolaou, D. (2013) 'Organization capital and the cross-section of expected returns', Journal of Finance, 68(4), pp. 1365-1406. doi: 10.1111/jofi.12034. Eli, A. and Lev, B. (1996) 'Value-relevance of nonfinancial information: The wireless communications industry Eli', Journal of Accounting and Economics, 22, pp. 3-30. Evenson, R. E. and Westphal, L. E. (1995) 'Technological Change and Technological 
Strategy', in J. Behrman and T. N. Srinivasan (ed.) Handbook of Development Economics. North-Holland. doi: 10.1016/S0022-3913(12)00047-9.

Feng, T., Cummings, L. and Tweedie, D. (2017) 'Exploring integrated thinking in integrated reporting - an exploratory study in Australia', Journal of Intellectual Capital. Emerald

Publishing Limited, 18(2), pp. 330-353. doi: 10.1108/JIC-06-2016-0068.

Frías-Aceituno, J. V., Rodríguez-Ariza, L. and García-Sánchez, I. M. (2013) 'Is integrated reporting determined by a country's legal system? An exploratory study', Journal of Cleaner Production, 44, pp. 45-55. doi: 10.1016/j.jclepro.2012.12.006.

García-Sánchez, I. M., Rodríguez-Ariza, L. and Frías-Aceituno, J. V. (2013) 'The cultural system and integrated reporting', International Business Review, 22(5), pp. 828-838. doi: 10.1016/j.ibusrev.2013.01.007.

Glauber, D. E. . F. and R. R. . (1967) 'Multicollinearity in Regression Analysis : The Problem Revisited', The Review of Economics and Statistics, 49(1), pp. 92-107. Available at: http://www.jstor.org/stable/1937887 M.

Global Reporting Initiative (GRI) (2012) Integrated Reporting. Available at: https://www.globalreporting.org/SiteCollectionDocuments/Integrated-reporting-monthlyreport-October-to-December-2011.pdf (Accessed: 7 October 2018).

Gourio, F. and Rudanko, L. (2014) 'Customer capital', Review of Economic Studies, 81(3), pp. 1102-1136. doi: 10.1093/restud/rdu007.

Griliches, Z. (1980) R\&D AND THE PRODUCTIVITY SLOWDOWN. 434. Cambridge. Available at: https://www.nber.org/papers/w0434.pdf (Accessed: 26 March 2019). Guthrie, J., Manes-Rossi, F. and Orelli, R. L. (2017) 'Integrated Reporting and Integrated Thinking in Italian Public Sector Organizations', Meditari Accountancy Research. Edited by C. de Villiers and C. de Villiers. Emerald Publishing Limited, pp. 1-38. doi: 10.1108/MEDAR-06-2017-0155.

Hansen, C. B. (2007) 'Generalized least squares inference in panel and multilevel models with serial correlation and fixed effects', Journal of Econometrics, 140, pp. 670-694. doi: 10.1016/j.jeconom.2006.07.011.

Hassel, L., Nilsson, H. and Nyquist, S. (2005) 'The value relevance of environmental performance', European Accounting Review, 14(1), pp. 41-61. doi:

$10.1080 / 0963818042000279722$.

Hill, C. W. L. and Jones, T. M. (1992) 'Stakeholder-Agency Theory', Journal of Management Studies, 29(2), pp. 131-154. doi: 10.1111/j.1467-6486.1992.tb00657.x.

Hirschey, M., Richardson, V. J. and Scholz, S. (2001) 'Value relevance of nonfinancial 
information: The case of patent data', Review of Quantitative Finance and Accounting, 17, pp. 223-235. doi: 10.1023/A:1012223625399.

Hsiao, P.-C. K. and Kelly, M. (2017) 'Investment considerations and impressions of integrated reporting', Sustainability Accounting, Management and Policy Journal, p. SAMPJ10-2016-0072. doi: 10.1108/SAMPJ-10-2016-0072.

Inkinen, H. (2015) 'Review of empirical research on intellectual capital and firm performance', Journal of Intellectual Capital, 16(3), pp. 518-565. doi: 10.1108/JIC-01-20150002.

Institute of Directors in Southern Africa (IDSA) (2002) King Report on Corporate Governance for South Africa.

Institute of Directors in Southern Africa (IDSA) (2009) King Report on Governance for South Africa. Available at:

https://cdn.ymaws.com/www.iodsa.co.za/resource/resmgr/king_iii/King_Report_on_Governa nce_fo.pdf (Accessed: 20 February 2019).

Institute of Directors in Southern Africa (IDSA) (2016) King IV Report on Corporate Governance for South Africa. Available at: http://www.iodsa.co.za/?page=KingIVEndorsers (Accessed: 20 February 2019).

International Integrated Reporting Council (IIRC) (2013) International $\langle I R\rangle$ framework, International Integrated Reporting Council (IIRC). London. doi: 10.2139/ssrn.2378899. International Integrated Reporting Council (IIRC) (2015) Creating value: Value to investors. London. doi: 10.1016/S0024-6301(97)81335-0.

Jensen, J. C. and Berg, N. (2012) 'Determinants of Traditional Sustainability Reporting Versus Integrated Reporting. An Institutionalist Approach', Business Strategy and the Environment, 21(5), pp. 299-316. doi: 10.1002/bse.740.

Jensen, M. C. and Meckling, W. H. (1976) 'Theory of the firm: Managerial Behavior, Agency Costs and Ownership Structure', Journal of Financial Economics. North-Holland Publishing Company, 3, pp. 305-360. Available at: https://ac.els-cdn.com/0304405X7690026X/1-s2.00304405X7690026X-main.pdf?_tid=acf5580a-1118-4674-9f4cc79b0ee271a7\&acdnat=1529317877_3251c0858def025fbafab65443fe9ed7 (Accessed: 18 June 2018).

Johannesburg Stock Exchange (JSE) (2004) Background and Selection Criteria. Available at: www.jse.co.za/sri. (Accessed: 22 February 2019).

Johannesburg Stock Exchange (JSE) (2016) 'JSE limited listings requirements', Johannesburg Stock Exchange, pp. 1-494. Available at: 
http://www.jse.co.za/content/JSERulesPoliciesandRegulationItems/JSE Requirements.pdf. Jones, S., Frost, G., Loftus, J. and Van Der Laan, S. (2007) 'An Empirical Examination of the Market Returns and Financial Performance of Entities Engaged in Sustainability Reporting', Australian Accounting Review, 17(1), pp. 78-87.

Kamukama, N., Ahiauzu, A. and Ntayi, J. M. (2011) 'Competitive advantage: mediator of intellectual capital and performance', Journal of Intellectual Capital, 12(1), pp. 152-164. doi:

$$
\text { 10.1108/14691931111097953. }
$$

Khalique, M., Bontis, N., Abdul, J., Bin Shaari, N. and Abu Hassan, M. I. (2015) 'Intellectual capital in small and medium enterprises in Pakistan', Journal of Intellectual Capital, 16(1), pp. 224-238. doi: 10.1108/02656710210415703.

Kothari, S. P. and Zimmerman, J. L. (1995) 'Price and return models', Journal of Accounting and Economics, 20(2), pp. 155-192. doi: 10.1016/0165-4101(95)00399-4.

KPMG (2014) Listing in Africa. Available at:

https://assets.kpmg/content/dam/kpmg/za/pdf/Listing-in-Africa-2014.pdf (Accessed: 15 March 2019).

Lee, K. W. and Yeo, G. H. H. (2016) 'The association between integrated reporting and firm valuation', Review of Quantitative Finance and Accounting. Springer US, 47(4), pp. 12211250. doi: 10.1007/s11156-015-0536-y.

Lev, B., Radhakrishnan, S. and Evans, P. C. (2016) Organizational Capital A CEO's Guide to Measuring and Managing Enterprise Intangibles, Measuring and Managing Organizational Capital Series.

Lev, B., Radhakrishnan, S. and Zhang, W. (2009) 'Organization Capital', Abacus, 45(3), pp. 275-298. doi: 10.1111/j.1467-6281.2009.00289.x.

Lev, B. and Sougiannis, T. (1996) 'The capitalization, amortization, and value-relevance of R\&D', Journal of Accounting and Economics, 21(1), pp. 107-138. doi: 10.1016/01654101(95)00410-6.

Lev, B. and Zarowin, P. (1999) 'The Boundaries of Financial Reporting and How to Extend Them', Journal of Accounting Research, 37(2), p. 353. doi: 10.2307/2491413.

Martín-de-Castro, G., Navas-López, J. E., López-Sáez, P. and Alama-Salazar, E. (2006) 'Organizational capital as competitive advantage of the firm', Journal of Intellectual Capital, 7(3), pp. 324-337. doi: 10.1108/14691930610681438.

Martínez-Ferrero, J. and Frías-Aceituno, J. V. (2013) 'Relationship between sustainable development and financial performance: International empirical research', Business Strategy and the Environment. doi: 10.1002/bse.1803. 
Menor, L. J., Kristal, M. M. and Rosenzweig, E. D. (2007) 'Examining the Influence of Operational Intellectual Capital on Capabilities and Performance', Manufacturing \& Service Operations Management, 9(4), pp. 559-578. doi: 10.1287/msom.1060.0131.

Mervelskemper, L. and Streit, D. (2017) 'Enhancing Market Valuation of ESG Performance: Is Integrated Reporting Keeping its Promise?', Business Strategy and the Environment, 26(4), pp. 536-549. doi: 10.1002/bse.1935.

Miles, S. J. and Van Clieaf, M. (2017) 'Strategic fit: Key to growing enterprise value through organizational capital', Business Horizons. 'Kelley School of Business, Indiana University', 60(1), pp. 55-65. doi: 10.1016/j.bushor.2016.08.008.

Ohlson, J. (1995) 'Earnings, book-values, and dividends in equity valuation.', Contemporary Accounting Research, 11(2), pp. 661-687. doi: 10.1111/j.1911-3846.1995.tb00461.x.

Oliver, J., Vesty, G. and Brooks, A. (2016) 'Conceptualising integrated thinking in practice', Managerial Auditing Journal, 31(2), pp. 228-248. doi: 10.1108/MAJ-10-2015-1253. PricewaterhouseCoopers (PwC) (2013) Seizing opportunities with integrated thinking. Available at: https://www.pwc.co.uk/assets/pdf/integrated-thinking-flyer-dec-2013.pdf (Accessed: 20 February 2019).

PricewaterhouseCoopers (PwC) (2018) 2017 Africa Capital Markets Watch. Available at: www.pwc.co.za/capitalmarketswatch.

Reimsbach, D., Hahn, R. and Gürtürk, A. (2017) 'Integrated Reporting and Assurance of Sustainability Information: An Experimental Study on Professional Investors' Information Processing', European Accounting Review, 8180(January), pp. 1-23. doi:

10.1080/09638180.2016.1273787.

Samaniego, R. M. (2006) 'Organizational capital, technology adoption and the productivity slowdown', Journal of Monetary Economics, 53(7), pp. 1555-1569. doi: 10.1016/j.jmoneco.2005.06.002.

Schadewitz, H. and Niskala, M. (2010) 'Communication via responsibility reporing and its effect on ifrm value in Finland', Corporate Social Responsibility and Environmental Management, 17(2), pp. 96-106. doi: DOI: 10.1002/csr.234.

Schneider, M. (2018) 'Digitalization of Production, Human Capital, and Organizational Capital', in The impact of Digitalization in the Workplace, Professional and Practice-based Learning, pp. 39-52.

Scott, W. R. (2015) Financial Accounting Theory. Seventh Ed. Pearson Canada Inc. doi: 10.1016/0890-8389(88)90123-0.

Serafeim, G. (2015) 'Integrated reporting and investor clientele', Journal of Applied 
Corporate Finance, 27(2), pp. 34-51.

Setia, N., Abhayawansa, S., Joshi, M. and Huyunh, A. V. (2015) 'Integrated reporting in South Africa: some initial evidence', Sustainability Accounting, Management and Policy Journal, 6(3), pp. 397-424.

Slack, R. and Tsalavoutas, I. (2018) 'Integrated Reporting decision usefulness: mainstream equity market views', Accounting Forum. Stockton on Tees (January 2018), 42(2), pp. 184 198. Available at: https://ssrn.com/abstract=2959745.

Sliker, B. K. . (2007) '2007 R\&D Satellite Account Methodologies : R\&D Capital Stocks and Net Rates of Return', Bureau of Economic Analysis/National Science Foundation R\&D Satellite Account Background Paper, (December).

Sonnenberg, D. and Hamann, R. (2006) 'The JSE socially responsible investment index and the state of sustainability reporting in South Africa', Development Southern Africa, 23(2), pp. 305-320. doi: 10.1080/03768350600707942.

Stewart, L. S. (2015) 'Growing Demand for ESG Information and Standards: Understanding Corporate Opportunities as Well as Risks', Journal of Applied Corporate Finance, 27(2), pp. $58-63$.

Subramaniam, M. and Youndt, M. A. (2005) 'The Influence of Intellectual Capital on the types of innovative capabilities', Academy of Maagement Journal, 48(October), pp. 450-463. doi: 10.5465/AMJ.2005.17407911.

The South Africa Institute of Chareterd Accountants (SAICA) (2015) INTEGRATED THINKING An exploratory survey. Available at:

https://www.saica.co.za/Portals/0/Technical/Sustainability/SAICAIntegratedThinkingLandsca pe.pdf (Accessed: 20 February 2019).

Tseng, C. Y. and Goo, Y. J. J. (2005) 'Intellectual capital and corporate value in an emerging economy: Empirical study of Taiwanese manufacturers', $R \& D$ Management.

Wiley/Blackwell (10.1111), 35(2), pp. 187-201. doi: 10.1111/j.1467-9310.2005.00382.x.

Velte, P. and Stawinoga, M. (2016) 'Integrated reporting: The current state of empirical research, limitations and future research implications', Journal of Management Control, pp. 1-46. doi: 10.1007/s00187-016-0235-4.

Venieris, G., Naoum, V. C. and Vlismas, O. (2015) 'Organisation capital and sticky behaviour of selling, general and administrative expenses', Management Accounting Research. Elsevier Ltd, 26(2014), pp. 54-82. doi: 10.1016/j.mar.2014.10.003.

Wernerfelt, B. (1984) 'A Resource-Based View of the Firm', Strategic Management Journal, 5(2), pp. 171-180. Available at: 
http://www1.ximb.ac.in/users/fac/Amar/AmarNayak.nsf/dd5cab6801f1723585256474005327 c8/456e5a8383adcf07652576a0004d9ba5/\$FILE/RBV.pdf (Accessed: 31 July 2018).

World Intellectual Capital Initiative (WICI) (2016) WICI Intangibles Reporting Framework Version 1.0. Available at: http://www.wici-global.com/framework (Accessed: 20 February 2019).

Wu, S. H., Lin, L. Y. and Hsu, M. Y. (2007) 'Intellectual capital, dynamic capabilities and innovative performance of organisations', International Journal of Technology Management, 39(3/4), p. 279. doi: 10.1504/IJTM.2007.013496.

Yang, C. C. and Lin, C. Y. Y. (2009) 'Does intellectual capital mediate the relationship between HRM and organizational performance? Perspective of a healthcare industry in

Taiwan', The International Journal of Human Resource Management. Taylor \& Francis Group, 20(9), pp. 1965-1984. doi: 10.1080/09585190903142415.

Youndt, M. A., Subramaniam, M. and Snell, S. A. (2004) 'Intellectual capital profiles: an examination of investments and returns', Journal of Management Studies, 41(2), pp. 335-361. Zhou, S., Simnett, R. and Green, W. (2017) 'Does Integrated Reporting Matter to the Capital Market ?', Abacus, 53(1). doi: 10.1111/abac.12104. 
Table 1: Sample Selection

\begin{tabular}{lr}
\hline Total number of active firms & $\mathbf{4 7 1}$ \\
\hline Firms of Financial Industry & 238 \\
\hline Non-listed companies over 2006-2015 period & 128 \\
\hline Firms wih no available data on SG\&A & 6 \\
\hline The final number of firms & 99 \\
\hline
\end{tabular}

Table 2: Sample classification by Industry

\begin{tabular}{lc}
\hline Industry & Number of firms \\
\hline Basic materials & 23 \\
Industrials & 27 \\
Consumer goods & 11 \\
Health care & 3 \\
Consumer services & 24 \\
Telecommunications & 2 \\
Technology & 9 \\
Total & 99 \\
\hline
\end{tabular}

Table 3: Number of observations specification

\begin{tabular}{lc}
\hline The initial number of observations & $\mathbf{1 0 9 0}$ \\
\hline Missing observations over 10 years & 100 \\
\hline Observations with negative Book Value & 6 \\
\hline Outliers a & 99 \\
\hline The final number of observations & 885 \\
\hline \multicolumn{1}{c}{ a observations were trimmed at 5\% level }
\end{tabular}

${ }^{a}$ observations were trimmed at $5 \%$ level

Table 4: Descriptive statistics

\begin{tabular}{llllll}
\hline Variable & Observations & Mean & Std. Dev. & Min & Max \\
\hline $\boldsymbol{M} \boldsymbol{V} \boldsymbol{S}_{i t}$ & 885 & 0.0430672 & 0.0472722 & 0.00045 & 0.1990878 \\
$\boldsymbol{O C}_{i t}$ & 935 & 6.129413 & 9.820889 & 0 & 44.09955 \\
$\boldsymbol{B V S}_{i t}$ & 886 & 18.66188 & 20.58392 & 0.3162576 & 82.88246
\end{tabular}




$\begin{array}{llllll}\boldsymbol{E P S}_{i t} & 886 & 4.443678 & 4.894643 & -0.4002185 & 19.08677 \\ \text { Size }_{i t} & 882 & 15.03133 & 1.752869 & 10.98127 & 18.02918 \\ \boldsymbol{L E V}_{i t} & 887 & 0.4819165 & 0.1721557 & 0.145367 & 0.8143749 \\ \boldsymbol{R O E}_{i t} & 886 & 0.2718191 & 0.1832612 & -0.1402985 & 0.8152155\end{array}$

Definition of variables: $M V S_{i t}$ - Market value of equity of firm $i$ at time $t, 4$ months after fiscal-year end, $O C_{i t}$ Organizational capital of equity of firm $i$ at time $t$ deflated by number of shares, $B V S_{i t}$ - Book value of equity scaled by total number of common shares of firm $i$ at time $t, E P S_{i t}$ - Earnings before interest and taxation of equity of firm $i$ at time $t$ scaled by total numbers of common shares, $D_{i t}$ - Binary variable, it takes 0 for the period before King III report adoption and 1 for the post-adoption period, Size $i t$ - Natural logarithm of total assets of firm $i$ at time $t, R O E_{i t}$ - Return on equity of equity of firm $i$ at time $t$ computed by ratio Earnings before interest and taxation over Book value, $L E V_{i t}$ - Leverage of firm $i$ at time $t$ measured by total liabilities scaled by total shares outstanding, Ind $d_{i t}$ - Multiple dummy variable based on 7 out of 10 industries of the industry classification benchmark

Table 5: Spearman-Pearson Correlation coefficients

\begin{tabular}{cllllllll}
\hline & $\boldsymbol{M V S}_{i t}$ & $\boldsymbol{O C}_{i t}$ & $\boldsymbol{B V S}_{i t}$ & $\boldsymbol{E P S}_{i t}$ & $\boldsymbol{D}_{i t}$ & $\boldsymbol{R O E}_{i t}$ & Size $_{i t}$ & LEV $_{i t}$ \\
\hline $\boldsymbol{M V S}_{i t}$ & 1 & $0.2629^{* *}$ & $0.7987^{* *}$ & $0.8449^{* *}$ & $0.0862^{* *}$ & $0.2848^{* *}$ & $0.6421^{* *}$ & $0.0869^{* *}$ \\
$\boldsymbol{O C}_{i t}$ & $0.2914^{* *}$ & 1 & $0.2347^{* *}$ & $0.2432^{* *}$ & $-0.0294^{* *}$ & $0.0688^{* *}$ & $0.1503^{* *}$ & $0.2018^{* *}$ \\
$\boldsymbol{B V S}_{i t}$ & $0.6486^{* *}$ & $0.2620^{* *}$ & 1 & $0.8125^{* *}$ & $0.1184^{* *}$ & $-0.0993^{* *}$ & $0.6426^{* *}$ & $0.0340^{* *}$ \\
$\boldsymbol{E P S}_{i t}$ & $0.7933^{* *}$ & $0.3675^{* *}$ & $0.7104^{* *}$ & 1 & 0.0135 & $0.4214^{* *}$ & $0.5345^{* *}$ & $0.1406^{* *}$ \\
$\boldsymbol{D}_{i t}$ & $0.1116^{* *}$ & $-0.1101^{* *}$ & $0.1067^{* *}$ & 0.0506 & 1 & $-0.2056^{* *}$ & $0.0946^{* *}$ & $0.0461^{* *}$ \\
$\boldsymbol{R O E}_{i t}$ & $0.2236^{* *}$ & $0.1305^{* *}$ & $-0.1258^{* *}$ & $0.2749^{* *}$ & $-0.1765^{* *}$ & 1 & -0.0101 & $0.2103^{* *}$ \\
$\boldsymbol{S i z e}_{i t}$ & $0.4992^{* *}$ & $0.2109^{* *}$ & $0.5301^{* *}$ & $0.4693^{* *}$ & $0.0863^{* *}$ & 0.0633 & 1 & $0.3447^{* *}$ \\
$\boldsymbol{L E V}_{i t}$ & $0.0868^{* *}$ & $0.1132^{* *}$ & -0.0649 & $0.1421^{* *}$ & 0.0111 & $0.2610^{* *}$ & $0.2791^{* *}$ & 1 \\
\hline
\end{tabular}

Spearman's rank correlation coefficients and Pearson's correlation coefficients are provided above and below the diagonal respectively

Significance level: $1 \% * * *, 5 \% * *, 10 \% *$

Definition of variables: $M V S_{i t}$ - Market value of equity of firm $i$ at time $t, 4$ months after fiscal-year end, $O C_{i t}$ Organizational capital of equity of firm $i$ at time $t$ deflated by number of shares, $B V S_{i t}$ - Book value of equity scaled by total number of common shares of firm $i$ at time $t, E P S_{i t}$ - Earnings before interest and taxation of equity of firm $i$ at time $t$ scaled by total numbers of common shares, $D_{i t}$ - Binary variable, it takes 0 for the period before King III report adoption and 1 for the post-adoption period, Size $e_{i t}$ - Natural logarithm of total assets of firm $i$ at time $t, R O E_{i t}$ - Return on equity of equity of firm $i$ at time $t$ computed by ratio Earnings before interest and taxation over Book value , $L E V_{i t}$ - Leverage of firm $i$ at time $t$ measured by total liabilities scaled by total shares outstanding, $I n d_{i t}$ - Multiple dummy variable based on 7 out of 10 industries of the industry classification benchmark

Table 6: Variation Inflation Factor

\begin{tabular}{lll}
\hline Variable & VIF & $\mathbf{1 / V I F}$ \\
\hline $\boldsymbol{O C}_{\text {it }}$ & 1.21 & 0.823933 \\
$\boldsymbol{B V S}_{i t}$ & 4.26 & 0.234762 \\
$\boldsymbol{E P S}_{i t}$ & 4.15 & 0.240962 \\
$\boldsymbol{D}_{i t}$ & 1.12 & 0.895086
\end{tabular}




$\begin{array}{lll}\text { Size }_{i t} & 1.74 & 0.574560 \\ \text { LEV }_{i t} & 1.36 & 0.737344 \\ \text { ROE }_{i t} & 2.01 & 0.496499\end{array}$

Definition of variables: $M V S_{i t}$ - Market value of equity of firm $i$ at time $t, 4$ months after fiscal-year end, $O C_{i t}$ Organizational capital of equity of firm $i$ at time $t$ deflated by number of shares, $B V S_{i t}$ - Book value of equity scaled by total number of common shares of firm $i$ at time $t, E P S_{i t}$ - Earnings before interest and taxation of equity of firm $i$ at time $t$ scaled by total numbers of common shares, $D_{i t}$ - Binary variable, it takes 0 for the period before King III report adoption and 1 for the post-adoption period, Size $e_{i t}$ - Natural logarithm of total assets of firm $i$ at time $t, R O E_{i t}$ - Return on equity of equity of firm $i$ at time $t$ computed by ratio Earnings before interest and taxation over Book value, $L E V_{i t}$ - Leverage of firm $i$ at time $t$ measured by total liabilities scaled by total shares outstanding, Ind $d_{i t}$ - Multiple dummy variable based on 7 out of 10 industries of the industry classification benchmark

Table 7: Market value model results

\begin{tabular}{|c|c|c|}
\hline & $M V S_{i t}$ & $z$-statistics \\
\hline$O C_{i t}$ & $0.0002 *$ & 1.73 \\
\hline$B V S_{i t}$ & $0.0009 * * *$ & 6.26 \\
\hline$E P S_{i t}$ & $0.0036 * * *$ & 6.51 \\
\hline$D_{i t}$ & 0.0067 & 0.016 \\
\hline Size $_{i t}$ & $0.0049 * * *$ & 6.35 \\
\hline$L E V_{i t}$ & $-0.0199 * * *$ & -2.84 \\
\hline$R O E_{i t}$ & $0.02627 * * *$ & 3.12 \\
\hline$O C_{i t} \times D_{i t}$ & $0.0009 * * *$ & 4.23 \\
\hline$B V S_{i t} x D_{i t}$ & $-0.0007 * * *$ & -4.27 \\
\hline$E P S_{i t} x D_{i t}$ & $0.0019 * * *$ & 2.88 \\
\hline Intercept & $-0.0648 * * *$ & -6.41 \\
\hline Industry effects & Yes & \\
\hline
\end{tabular}

$$
\begin{gathered}
\text { Significance level: } 1 \% * * *, 5 \% * *, 10 \% * \\
M V S_{i t}=a_{0}+a_{1} O C_{i t}+a_{2} B V S_{i t}+a_{3} E P S_{i t}+a_{4} D_{i t}+a_{5}\left(O C_{i t} \times D_{i t}\right)+a_{6}\left(B V S_{i t} \times D_{i t}\right)+a_{7}\left(E P S_{i t} \times D_{i t}\right)+ \\
a_{8} \text { Size }_{i t}+a_{9} R O E_{i t}+a_{10} L E V_{i t}+\sum_{j=1}^{7} a_{11} I n d_{i t}+e_{i t}
\end{gathered}
$$

Definition of variables: $M V S_{i t}$ - Market value of equity of firm $i$ at time $t, 4$ months after fiscal-year end, $O C_{i t}$ Organizational capital of equity of firm $i$ at time $t$ deflated by number of shares, $B V S_{i t}$ - Book value of equity scaled by total number of common shares of firm $i$ at time $t, E P S_{i t}$ - Earnings before interest and taxation of equity of firm $i$ at time $t$ scaled by total numbers of common shares, $D_{i t}$ - Binary variable, it takes 0 for the period before King III report adoption and 1 for the post-adoption period, Size $e_{i t}$ - Natural logarithm of total assets of firm $i$ at time $t, R O E_{i t}$ - Return on equity of equity of firm $i$ at time $t$ computed by ratio Earnings before interest and taxation over Book value, $L E V_{i t}$ - Leverage of firm $i$ at time $t$ measured by total liabilities scaled by total shares outstanding, Ind $d_{i t}$ - Multiple dummy variable based on 7 out of 10 industries of the industry classification benchmark

Table 8: Return model results

\begin{tabular}{lll}
\hline & $\boldsymbol{R}_{i t}$ & Z-statistic \\
\hline $\boldsymbol{O C}_{\text {it }}$ & 0.0948811 & 1.19 \\
$\boldsymbol{B} \boldsymbol{V} \boldsymbol{S}_{i t}$ & 0.0033922 & 1.99
\end{tabular}




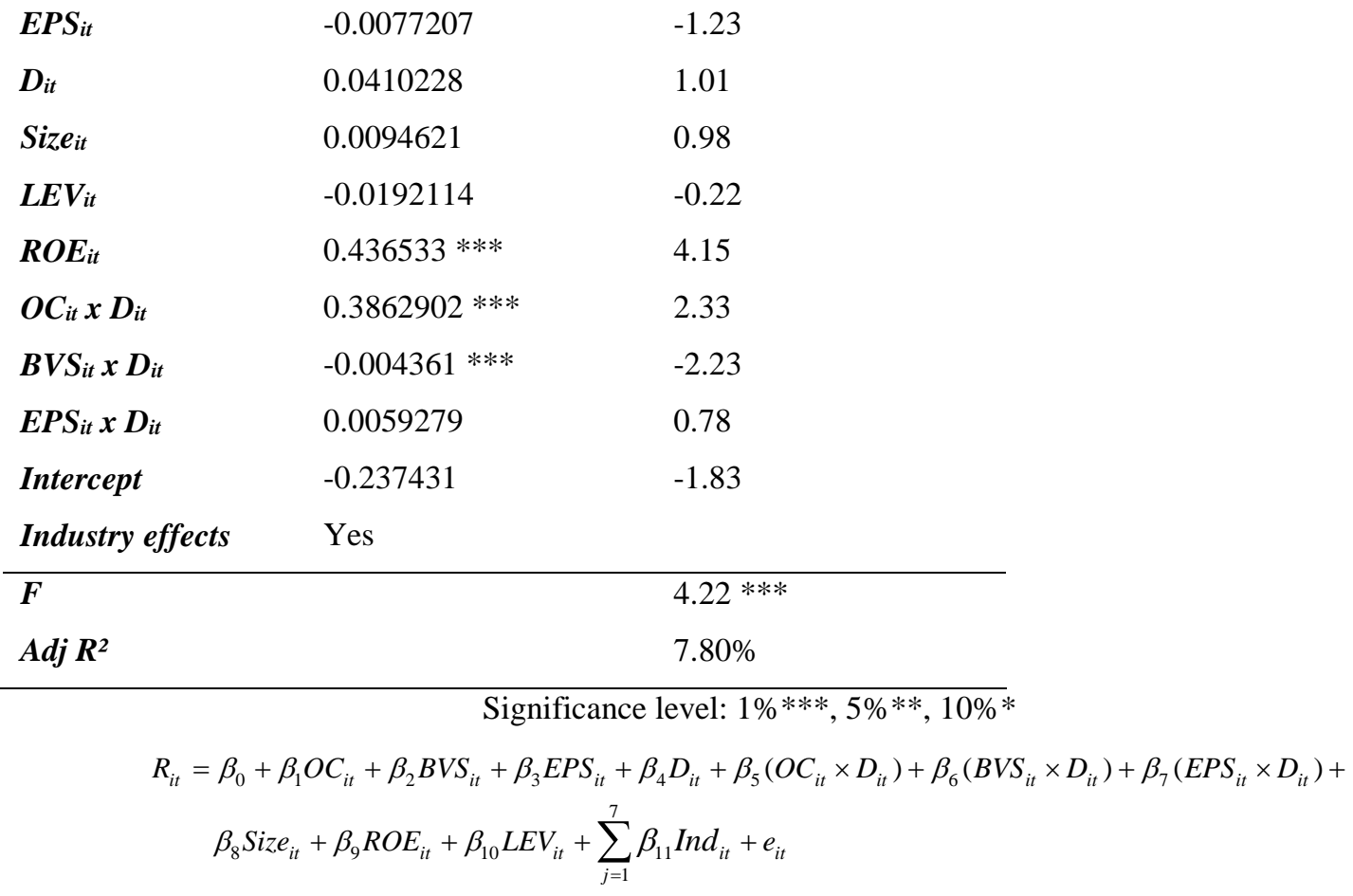

Definition of variables: $M V S_{i t}$ - Market value of equity of firm $i$ at time $t, 4$ months after fiscal-year end, $O C_{i t}$ Organizational capital of equity of firm $i$ at time $t$ deflated by number of shares, $B V S_{i t}$ - Book value of equity scaled by total number of common shares of firm $i$ at time $t, E P S_{i t}$ - Earnings before interest and taxation of equity of firm $i$ at time $t$ scaled by total numbers of common shares, $D_{i t}$ - Binary variable, it takes 0 for the period before King III report adoption and 1 for the post-adoption period, Size $i t$ - Natural logarithm of total assets of firm $i$ at time $t, R O E_{i t}$ - Return on equity of equity of firm $i$ at time $t$ computed by ratio Earnings before interest and taxation over Book value, $L E V_{i t}$ - Leverage of firm $i$ at time $t$ measured by total liabilities scaled by total shares outstanding, Ind $d_{i t}$ - Multiple dummy variable based on 7 out of 10 industries of the industry classification benchmark 